University of Nebraska - Lincoln

DigitalCommons@University of Nebraska - Lincoln

Faculty Publications from the Harold W. Manter Laboratory of Parasitology

2003

\title{
Eimeria Species from Serows (Capricornis spp.) in Japan with Descriptions of Two New Species
}

\author{
Lee Couch \\ University of New Mexico, Icouch@unm.edu \\ Shigehiko Uni \\ Osaka City University Medical School \\ Donald W. Duszynski \\ University of New Mexico, eimeria@unm.edu
}

Follow this and additional works at: https://digitalcommons.unl.edu/parasitologyfacpubs

Part of the Parasitology Commons

Couch, Lee; Uni, Shigehiko; and Duszynski, Donald W., "Eimeria Species from Serows (Capricornis spp.) in Japan with Descriptions of Two New Species" (2003). Faculty Publications from the Harold W. Manter Laboratory of Parasitology. 142.

https://digitalcommons.unl.edu/parasitologyfacpubs/142

This Article is brought to you for free and open access by the Parasitology, Harold W. Manter Laboratory of at DigitalCommons@University of Nebraska - Lincoln. It has been accepted for inclusion in Faculty Publications from the Harold W. Manter Laboratory of Parasitology by an authorized administrator of DigitalCommons@University of Nebraska - Lincoln. 


\title{
EIMERIA SPECIES FROM SEROWS (CAPRICORNIS SPP.) IN JAPAN WITH DESCRIPTIONS OF TWO NEW SPECIES
}

\author{
Lee Couch, Shigehiko Uni, and Donald W. Duszynski \\ Department of Biology, The University of New Mexico, Albuquerque, New Mexico 87131. e-mail: Icouch@unm.edu
}

\begin{abstract}
Fresh fecal samples from 35 Japanese serows Capricornis crispus (Temminck, 1845), and 5 Formosan serows Capricornis swinhoei Gray, 1862, were collected between October 1998 and March 1999. Eimeriid coccidians were found in 12 (34\%) Japanese serows and in 1 (20\%) Formosan serow. Three Eimeria species were found, and 2 are described here as new. The third species is consistent with the description of Eimeria kamoshika Inoue, 1989. Sporulated oocysts of 1 new species are broadly ellipsoidal, $20.7 \times 16.8 \mu \mathrm{m}(18-23 \times 14-19 \mu \mathrm{m})$ with a length $(\mathrm{L})$ :width $(\mathrm{W})$ ratio of $1.2(1.1-1.4)$; these lack a micropyle (M) and oocyst residuum (OR) but 1-2 polar granules (PGs) are sometimes present. Sporocysts are elongate-ellipsoidal, $10.5 \times 5.9 \mu \mathrm{m}(9-13 \times 5-7 \mu \mathrm{m})$, with a L/W ratio of $1.8(1.5-2.4)$, and have a Stieda body $(\mathrm{SB})$ and sporocyst residuum (SR). Oocysts of the second new species are broadly ovoidal, $28.2 \times 22.0 \mu \mathrm{m}(25-33 \times 19-23 \mu \mathrm{m})$, with a L/W of 1.3 (1.1-1.5), and have a $\mathrm{M}$ at the slightly pointed end, but lack an OR and PG. Sporocysts are ellipsoidal, $12.9 \times 8.1 \mu \mathrm{m}(11-15 \times 7-10)$, with a L/W of $1.6(1.3-1.9)$, and have a SB and SR.
\end{abstract}

The family Bovidae (Artiodactyla) is a complex family of ruminants, with at least 9 subfamilies (Grubb, 1993). One of these, Caprinae Gray, 1821, has 3 evolutionary lineages (tribes): the Rupicaprini (goat-antelopes), the Caprini (sheep and goats), and the Oviboni (shrub-oxen, musk-oxen, and others). Geist (1987) postulated that characteristics of the Caprini that distinguish them from the Rupicaprini are a consequence of their open habitats and of their migration into areas with seasonal cold climates. Among the goat-antelopes are the serows, Capricornis species, in a genus that unites serows and gorals (3 species each, Geist, 1987; Grubb, 1993). Serows are medium-sized herbivores $(30-45 \mathrm{~kg}$ ) that forage on grasses, broad-leafed trees, and bamboo in summer and on needle-leaf trees, including Japanese cypress, in winter. Their estimated life span in the wild is about $6 \mathrm{yr}$, but some captive animals have exceeded $20 \mathrm{yr}$ of age (S. Uni, pers. obs.). There are 3 known serow species: Capricornis crispus is endemic in Japan (estimated population, 50,000), Capricornis swinhoei inhabits Taiwan only, and Capricornis sumatraensis is found in southeast Asia, particularly Indonesia and Sumatra (Grubb, 1993). Japanese serows (C. crispus) are indigenous to the mountains of Honshu, Shikoku, and Kyushu, usually found at altitudes higher than $1,000 \mathrm{~m}$; they are officially designated part of the Japanese national heritage and are strictly protected by the government. In collaboration with Osaka City University (Japan) and the University of New Mexico (U.S.A.), we had the opportunity to examine feces of wild indigenous serows ( $C$. crispus) as well as of captive Formosan serows ( $C$. swinhoei). In this study, we report the results of our observations on the coccidia found in these uncommon animals.

\section{MATERIALS AND METHODS}

Forty fecal samples from serows were collected in Japan between October 1998 and March 1999 in accordance with the policies of the Japanese Ministry of the Environment. Thirty animals were shot and dissected at the Animal Husbandry Research Center in Yamagata Prefecture, Honshu, and feces were taken directly from the rectum. Two other serows (C. crispus) found on Mt. Ena, Gifu Prefecture, were too ill to move; these animals were humanely killed and necropsied, and feces were collected from the rectum. Eight samples ( 2 from C. crispus

Received 25 November 2002; revised 3 March 2003; accepted 3 March 2003.

* Department of Medical Zoology, Osaka City University Medical School, Osaka, Japan and 5 from $C$. swinhoei from Mie Prefecture and 1 from C. crispus from Gifu Prefecture) were collected directly from captive animals. Fecal material was placed in vials containing $2 \%(\mathrm{w} / \mathrm{v})$ aqueous potassium dichromate $\left(\mathrm{K}_{2} \mathrm{Cr}_{2} \mathrm{O}_{7}\right)$ solution, mixed thoroughly, and refrigerated for 2-3 days before being shipped to the United States. Upon receipt at the University of New Mexico, the samples were stored at ambient temperature for $\sim 2-3 \mathrm{mo}$, until they could be processed as detailed by Duszynski and Wilber (1997), and were screened for coccidia. Oocysts were measured and photographed using both bright field and Nomarski differential interference contrast microscopy. Standardized abbreviations for oocyst and sporocyst structures are those used by Wilber et al. (1998): oocyst characters - length (L) and width (W) with their ranges and ratios $(\mathrm{L} / \mathrm{W})$, micropyle $(\mathrm{M})$, residuum $(\mathrm{OR})$, and polar granules (PG); sporocyst characters-L, W, their ranges and L/W, Stieda body (SB), substieda body (SSB), parastieda body (PSB), residuum (SR), sporozoites (SP), refractile bodies (RB), and nucleus (N) in SP. All measurements are given in micrometers $(\mu \mathrm{m})$, with size ranges in parentheses after the means.

\section{RESULTS}

Of the 40 serows examined for coccidia (Table I), $13(32 \%)$ had eimerian oocysts in their feces; 12 of 35 (34\%) samples from $C$. crispus and 1 of $5(20 \%)$ from $C$. swinhoei were positive.

\section{DESCRIPTION}

\section{Eimeria kamoshika Inoue, 1989}

(Figs. 1, 2, 7)

Description of sporulated oocyst: Oocyst shape-elongateellipsoidal, slightly asymmetrical; number of walls-2; wall thickness-1.5; wall characteristics - outer, smooth and brownish; inner, smooth and colorless, approximately half of total thickness; $\mathrm{L} \times \mathrm{W}(\mathrm{n}=50)-29.1 \times 16.6(24-32 \times 14-22)$; L/W-1.8 (1.3-2.3); M-present as a flattened area at the end near the M; OR-absent; PGs-1-3. Distinctive features of oocyst-asymmetrical shape, flattened end near $\mathrm{M}$.

Description of sporocyst and SP: Sporocyst shape-broadly ellipsoidal to subspheroidal; $\mathrm{L} \times \mathrm{W}-7.7 \times 5.3(6-10.5 \times 4-$ 7.5); L/W-1.5 (1.1-1.8); SB-present, somewhat indistinct; SSB — absent; PSB — absent; SR_present; SR characteristics— a cluster of medium-sized granules lying in center and to 1 side of sporocyst; $\mathrm{SP}$-lie head to tail and have a large $\mathrm{RB}$ that appears to be subcentrally located. Distinctive features of sporocyst-none. 
TABLE I. Serows (Capricornis crispus, Capricornis swinhoei) collected from three prefectures in Honshu, Japan, and examined for coccidia.*

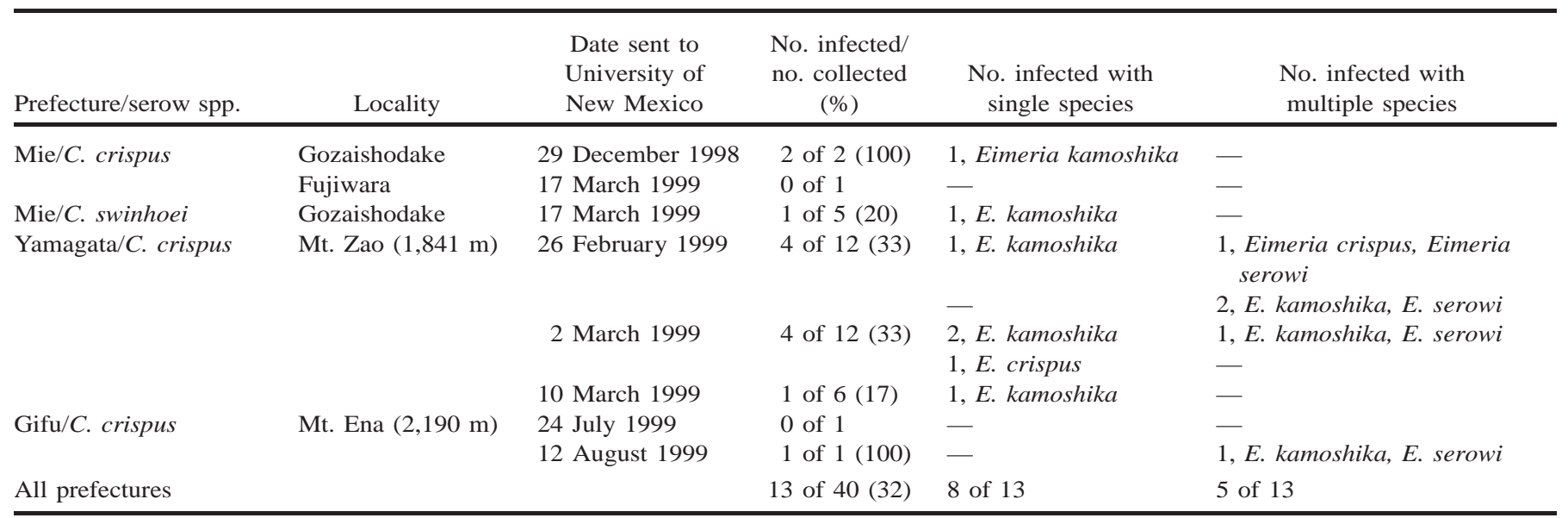

\section{Taxonomic summary}

Type host: Capricornis crispus (Temminck, 1845), Japanese serow.

Other hosts: Capricornis swinhoei (Gray, 1862), Formosan serow (in Japan).

Type locality: Nagano Prefecture, Honshu, Japan.

Geographic distribution: Honshu, Gifu, Mie, Nagano, and Yamagata prefectures, Japan.

Prevalence: Four of 214 (2\%, original description) and 10 of 35 (29\%, this study) in C. crispus; 1 of 5 (20\%) in C. swinhoei (this study).

Sporulation: Exogenous (Inoue, 1989).

Prepatent and patent periods: Unknown.

Site of infection: Unknown. Oocysts recovered from feces.

Material deposited: Photosyntypes of sporulated oocysts deposited in the U.S. National Parasite Collection (USNPC), Beltsville, Maryland, No. 92568.

\section{Remarks}

This species was first described by Inoue (1989), who found it in only 4 of 214 (2\%) C. crispus carcasses brought to Nihon University, Kanagawa, Japan. The oocysts measured by him were $30.0 \times 14.9(25-33 \times 11-16.5)$, with a L/W of $2.1(1.8-$ 2.7); the sporocysts were $8-10 \times 6-7$, without means or L/W. The only mensural difference between the oocysts described by Inoue (1989) and those observed by us is that the oocysts in the present study were slightly wider. Inoue did not provide a line drawing of the oocyst (included in this article [Fig. 7]) or deposit type (photosyntype) specimens in any known collection, which has been done by us. Finally, he was unable to crosstransmit E. kamoshika to two 2-mo-old domestic goats. The combination of quantitative and qualitative characters reported in our 2 studies distinguish these oocysts from those of all other species described from other Rupicaprini.

\section{Eimeria serowi n. sp.}

(Figs. 3, 4, 8)

Description of sporulated oocyst: Oocyst shape-broadly ellipsoidal; number of walls-2; wall thickness-1.5; wall characteristics—outer, approximately two-thirds of total thickness, smooth to lightly pitted and appears somewhat striated in optical cross-section; inner darker, $\sim 0.5 ; \mathrm{L} \times \mathrm{W}(\mathrm{N}=50)-20.7$ $\times 16.8(18-23 \times 14-19) ; \mathrm{L} / \mathrm{W}-1.2(1.1-1.4) ; \mathrm{M}$-absent; OR - absent; PGs-0-2. Distinctive features of oocyst-lightly striated outer wall.

Description of sporocyst and SP: Sporocyst shape-elongate-ellipsoidal; $\mathrm{L} \times \mathrm{W}-10.5 \times 5.9(9-13 \times 5-7)$; L/W-1.8 (1.5-2.4); SB-present, broad and prominent; SSB-absent; PSB — absent; SR — present; SR characteristics—small granules lying in center of sporocyst between SP; SP-lie head to tail and have a large posterior RB. Distinctive features of sporocyst-elongate-ellipsoidal shape and prominent SB.

\section{Taxonomic summary}

Type host: Capricornis crispus (Temminck, 1845), Japanese serow.

Other hosts: None known to date.

Type locality: Mt. Zao, Yamagata Prefecture, Honshu, Japan. Geographic distribution: Gifu and Yamagata prefectures, Honshu, Japan.

Prevalence: Five of 35 (14\%) C. crispus; 0 of 5 C. swinhoei. Sporulation: Probably exogenous. Fecal suspensions of oocysts were kept in vials of $2 \%(\mathrm{w} / \mathrm{v})$ aqueous $\mathrm{K}_{2} \mathrm{Cr}_{2} \mathrm{O}_{7}$ solution for 2-3 mo at $\sim 24 \mathrm{C}$ before oocyst discovery and measurement.

Prepatent and patent periods: Unknown.

Site of infection: Unknown. Oocysts recovered from feces.

Material deposited: Photosyntypes of sporulated oocysts deposited in the USNPC, Beltsville, Maryland, No. 92567.

Etymology: The nomen triviale is derived from the common name of the type host, with the genitive singular ending, meaning "of the serow."

\section{Remarks}

Sporulated oocysts of this species are similar in size to those of Eimeria naganoensis $(16.5-23 \times 14-18$, mean $20.0 \times 15.8)$ from $C$. crispus collected in Nagano Prefecture by Inoue (1989). They differ, however, in the lack of a M, which is present in E. naganoensis, and in having 1-2 PGs, which E. naganoensis lacks. Also, the SPs of E. naganoensis have both tiny 

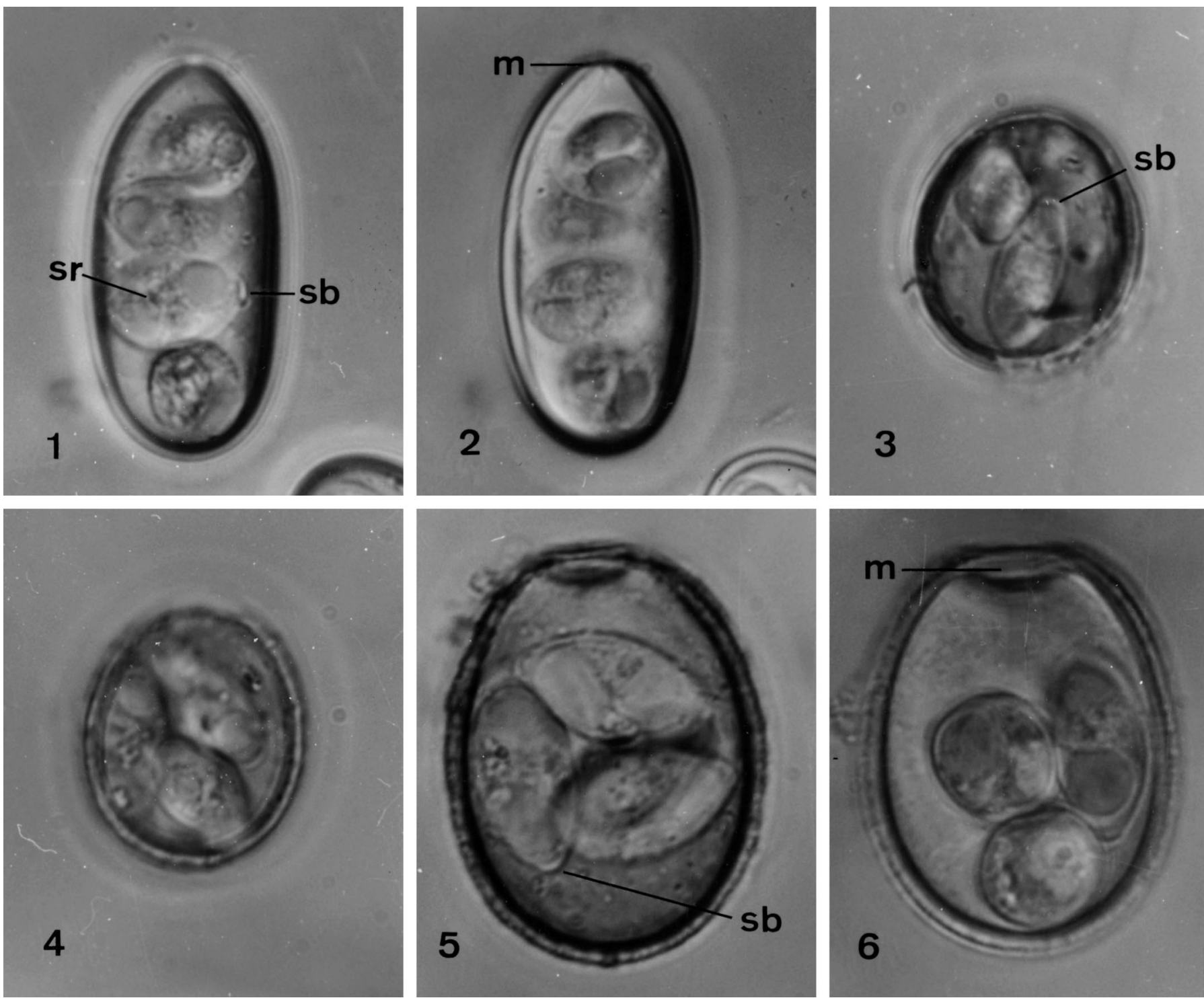

FiguRES 1-6. Photomicrographs of sporulated oocysts of Eimeria kamoshika $(1,2)$, Eimeria serowi $(3,4)$, and Eimeria crispus $(5,6)$ from C. crispus collected on Mt. Zao, Yamagata Prefecture, Honshu, Japan. Bar $=10 \mu \mathrm{m}$. 1, 2. Note asymmetrical shape of oocyst, presence of an M (but no M cap), sporocyst shape, presence of an SB, and SR. 3, 4. Note mildly striated appearance of oocyst wall(s) in optical cross section, apparent lack of an M, ellipsoidal shape of sporocyst, presence of an SB, and SR. 5, 6. Note thick, striated oocyst wall, presence of a wide M, ellipsoidal shape of sporocyst, presence of an SB, and SR. Abbreviations: m, micropyle of oocyst; sb, Stieda body; sr, sporocyst residuum.

and large RBs in each SP, although only a single, large, rounded $\mathrm{RB}$ is seen at the rounded end of each $\mathrm{SP}$ in E. serowi.

\section{Eimeria crispus n. sp.}

(Figs. 5, 6, 9)

Description of sporulated oocyst: Oocyst shape-broadly ovoidal; number of walls -2 ; wall thickness $->1.5$; wall characteristics - smooth, slightly pitted giving a striated appearance in optical cross-section; $\mathrm{L} \times \mathrm{W}(\mathrm{N}=25)-28.2 \times 22.0(25-33$ $\times 19-23) ; \mathrm{L} / \mathrm{W}-1.3(1.1-1.5) ; \mathrm{M}-$ present at slightly pointed end of oocyst, $\sim 7.5$ wide; OR—absent; PG—absent. Distinctive features of oocyst-large size, thick wall, and wide M.

Description of sporocyst and SP: Sporocyst shape-ellipsoidal; $\mathrm{L} \times \mathrm{W}-12.9 \times 8.1(11-15 \times 7-10) ; \mathrm{L} / \mathrm{W}-1.6(1.3-1.9)$;
SB - present; SSB - absent; PSB - absent; SR - present; SR characteristics - a few to many scattered granules or a compact mass, usually in middle of sporocyst between SP or in middle along 1 side of sporocyst; $\mathrm{SP}$-large anterior and posterior RBs that obscure the SP. Distinctive features of sporocyst-2 large $\mathrm{RBs}$ in SP.

\section{Taxonomic summary}

Type host: Capricornis crispus (Temminck, 1845), Japanese serow.

Other hosts: None known to date.

Type locality: Mt. Zao, Yamagata Prefecture, Honshu, Japan. Geographic distribution: Honshu, Japan.

Prevalence: Two of $35(6 \%)$ C. crispus; 0 of 5 C. swinhoei. 

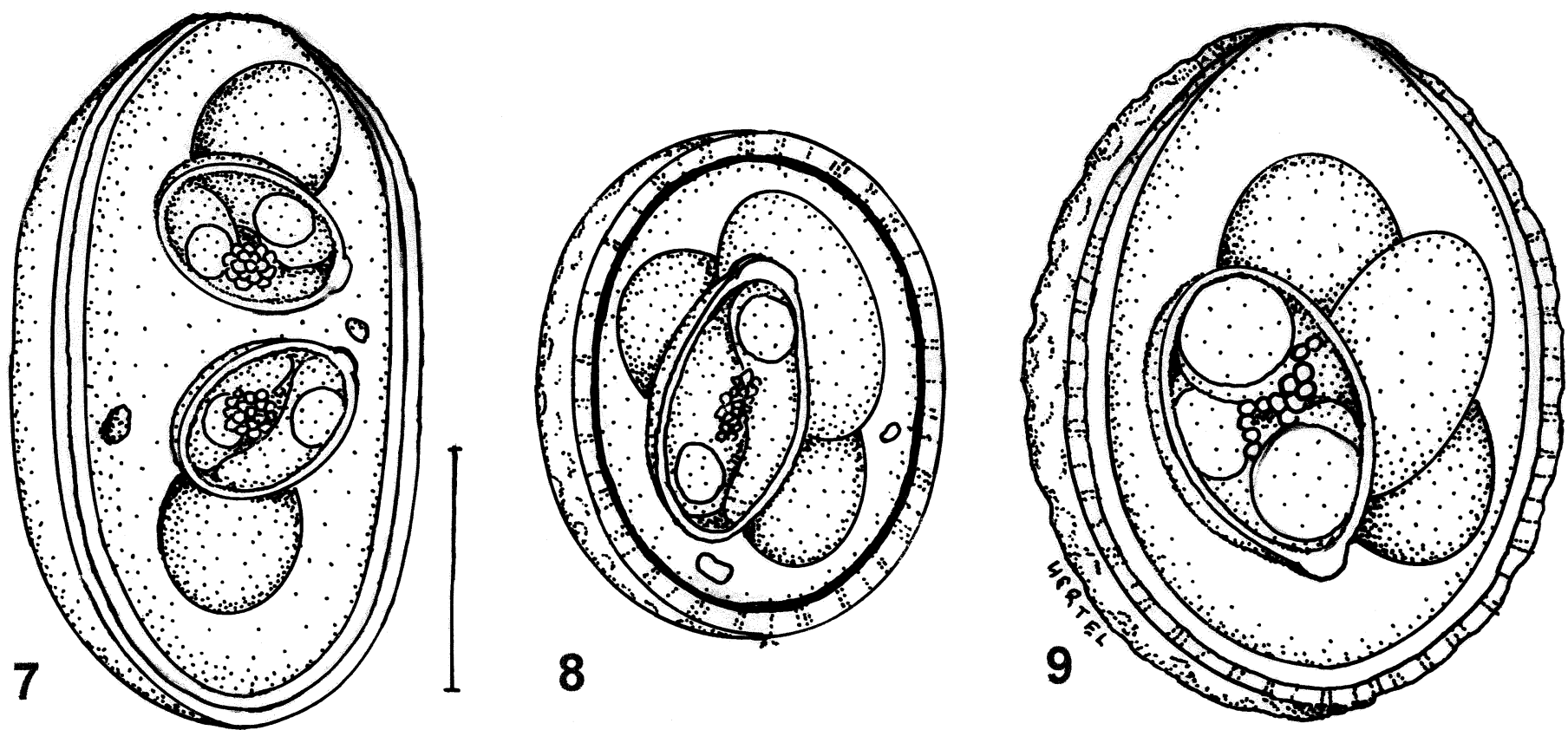

Figures 7-9. Line drawings of sporulated oocysts. 7. E. kamoshika. 8. E. serowi. 9. E. crispus. Bar = 10 $\mu$ m.

Sporulation: Probably exogenous. Fecal suspensions of oocysts were kept in vials of $2 \%(\mathrm{w} / \mathrm{v})$ aqueous $\mathrm{K}_{2} \mathrm{Cr}_{2} \mathrm{O}_{7}$ solution for 2-3 mo at $\sim 24 \mathrm{C}$ before oocyst discovery and measurement. Prepatent and patent periods: Unknown.

Site of infection: Unknown. Oocysts recovered from feces.

Material deposited: Photosyntypes of sporulated oocysts deposited in the USNPC, Beltsville, Maryland, No. 92566.

Etymology: The nomen triviale is derived from the specific epithet of the host name, maintaining the nominative singular ending.

\section{Remarks}

Remarks: The sporulated oocysts of this species are similar in size to those of Eimeria nihonis (28-33 × 19-23, mean 29.7 $\times 21.0)$ from $C$. crispus collected in Nagano Prefecture by Inoue (1989) and to those of Eimeria gozaishoensis $(29.4 \times 20.8$, range not given) described from the Formosan serow (Japan Serow Center at Gozaishodake, Mie Prefecture, Japan), which Inoue and Imura (1991) called Capricornis crispus swinhoei (probably $C$. swinhoei). It differs from those of E. nihonis in having ellipsoidal (vs. ovoidal) sporocysts that have a distinct $\mathrm{SB}$, which those of $E$. nihonis lack. Its oocysts differ from those of E. gozaishoensis in having a striated oocyst wall (vs. smooth) and lacking a $\mathrm{M}$ cap, which is present in those of E. gozaishoensis.

\section{DISCUSSION}

Of the 6 species of serows and gorals in Capricornis, only 2 have been examined for coccidia in just 3 studies of these parasites (Inoue, 1989; Inoue and Imura, 1991; present study), and 7 coccidia species have been described: Eimeria capricornis, E. crispus, E. kamoshika, E. naganoensis, E. nihonis, and E. serowi from the Japanese serow (C. crispus) and E. gozaish- oensis and E. kamoshika from captive (in Japan) Formosan serows (C. swinhoei). Once adequate numbers of all Capricornis species have been examined, we predict that there may be more than 30 Eimeria species from this host genus.

With little known about these parasites at this time, few generalizations can be made. No life cycles or endogenous stages are known, no ultrastructural work has been done on any lifecycle stage, the prepatent and patent periods are unknown, and no genes of any serow coccidia have been sequenced. Only the structure of the sporulated oocyst is known for the 7 coccidian species discovered to date. The unifying structural features are a lack of an OR and the possession by the sporocysts of residua and SPs with at least 1 large RB at their rounded end. Also, all but E. nihonis have an SB, and all lack SSBs and PSBs. The lack of an OR and the presence of an SB in 6 of the 7 known species merits special mention in the present study.

The OR is thought to be a cluster of lipid granules eliminated from the cytoplasm of the zygote during sporogony (Kheysin, 1971), but it is unknown why some eimeriid coccidia have these granules and others do not. Also, its function, if any, is largely unknown. It is interesting to note, however, that all Eimeria species from cattle, sheep, and swine (Levine and Ivens, 1970; Levine, 1973) either lack an OR or none has yet been described from their sporulated oocysts. The SB of the sporocyst is a caplike structure that dissolves in the upper intestinal tract of the vertebrate host and, thus, provides an opening for the SPs to leave the sporocyst and enter the intestinal lumen and, ultimately, enterocytes. These structures are of interest because, recently, it has been shown that genetic lineages of coccidia can be distinguished through these structures (Barta et al., 1997; Zhao and Duszynski, 2001; Tenter et al., 2002). Two lineages of coccidia may inhabit serows, i.e., 1 of E. nihonis (without a $\mathrm{SB}$ ) and 1 of the other 6 species (with SB and without an OR).

Other qualitative and quantitative aspects of the oocysts and 
sporocysts differ among the 7 species and are not phylogenetically informative. For example, oocyst $\mathrm{L}$ and $\mathrm{W}$ vary considerably from the largest, E. capricornis $(42 \times 23)$, to the smallest, E. naganoensis $(20 \times 16)$; L/W are from $1.2($ E. serowi) to 2.1 (E. kamoshika), with the great variance in shape from subspheroidal to elongate-ellipsoidal. All but E. serowi have a M, but only E. gozaishoensis has a $\mathrm{M}$ cap. Only 2, E. capricornis and E. serowi, have polar bodies. Four have rough, pitted, or striated outer walls (E. capricornis, E. crispus, E. nihonis, and E. serowi), and the other 3 have smooth outer walls. The sporocysts are equally variable from the largest, E. capricornis $(15-23 \times 8-13)$, to the smallest, E. kamoshika $(8-10$ $\times 6-7$ ), and their shapes vary from subspheroidal (E. kamoshika) to elongate-ellipsoidal (E. serowi).

Clearly, there is still much work to be done with the coccidia of not only serows but of all Artiodactyla. Oocysts can be collected easily in the field (Japanese serows, in particular, defecate in only 1 spot in an area) and are the stage most used for the identification of coccidia, so vertebrate biologists, veterinarians, wildlife biologists, and others who work with ruminants can contribute to the understanding of coccidia from their particular host groups by collecting fecal samples to preserve oocysts as outlined by Duszynski and Wilber (1997).

\section{ACKNOWLEDGMENTS}

We are grateful to many coworkers in Japan but especially to Y. Suzuki, Gifu University, for the samples from Gifu Prefecture; A. Katsumi, Animal Husbandry Research Center, Yamagata-ken Agricultural Co-op; N. Mitani and T. Kurosaki of the Japan Wildlife Research Center, Tokyo, for their assistance with dissecting animals; Y. Mori, Japan Serow Center, Mie Prefecture, for the Mie samples; C. Latta for her critical review of the original draft of this manuscript; and L. Hertel for the line drawings. We thank M. Iseki, Kanazawa University, for his suggestions and partial financial support and Yamagata City for permission to study the serows. This work also was supported, in part, by NSF PEET grant DEB-9521687 to D.W.D.

\section{LITERATURE CITED}

Barta, J. R., D. S. Martin, P. A. Liberator, M. Dashkevicz, J. W. Anderson, S. D. Feighner, A. Elbrecht, A. Perkins-Barrow, M. C. Jenkins, H. D. Danforth, M. D. Ruff, and H. Profous-JuchELKA. 1997. Phylogenetic relationships among eight Eimeria species infecting domestic fowl inferred using complete small subunit ribosomal DNA sequences. Journal of Parasitology 83: 262-271.

DuszYNSKI, D. W., AND P. G. WILBER. 1997. A guideline for the preparation of species descriptions in the Eimeriidae. Journal of Parasitology 83: 333-336.

Geist, V. 1987. On the evolution of the Caprinae. In The biology and management of Capricornis and related mountain antelopes, $\mathrm{H}$. Soma (ed.). Croom Helm, New York, p. 3-40.

GrubB, P. 1993. Order Artiodactyla. In Mammal species of the world, D. E. Wilson and D. M. Reader (eds.). Smithsonian Institution Press, Washington, D.C., p. 377-414.

InOUE, I. 1989. Eimeria capricornis n. sp., E. nihonis n. sp., E. naganoensis n. sp., and E. kamoshika n. sp. (Protozoa: Eimeriidae) from the Japanese serow, Capricornis crispus. Japanese Journal of Veterinary Science 51: 163-168.

-, AND M. IMURA. 1991. Eimeria gozaishoensis n. sp. from the Formosan serow (Capricornis crispus swinhoei). Journal of Wildlife Diseases 27: 214-216.

KhEYsin, E. M. 1971. Life cycles of coccidia of domestic animals. University Park Press, Baltimore, p. 78-98 [translated by F. K. Plous Jr.]

Levine, N. D. 1973. Protozoan parasites of domestic animals and of man, 2nd ed. Burgess Publishing, Minneapolis, Minnesota, 406 p. , AND V. Ivens. 1970. The coccidian parasites (Protozoa, Sporozoa) of ruminants. Illinois Biological Monographs, No. 44, University of Illinois Press, Urbana, Illinois.

Tenter, A. M., J. R. Barta, I. Beveridge, D. W. Duszynski, H. Mehlhorn, D. A. Morrison, R. C. A. Thompson, ANd P. A. ConRad. 2002. The conceptual basis for a new classification of the coccidia. International Journal of Parasitology 32: 595-616.

Wilber, P. G., D. W. Duszynski, S. J. Upton, R. S. Seville, and J. O. CoRLISS. 1998. A revision of the taxonomy and nomenclature of the Eimeria spp. (Apicomplexa: Eimeriidae) from rodents in the Tribe Marmotini (Sciuridae). Systematic Parasitology 39: 113-135.

ZhaO, X., AND D. W. DusZYNSKI. 2001. Molecular phylogenies suggest the OR can be used to distinguish two independent lineages of Eimeria spp. in rodents. Parasitology Research 87: 638-643. 